\title{
An Assessment on Role of Media in Fashion Adoptions among Young Adults Girls
}

\author{
Shikha Johari, Ragini Mishra and Alka Pandey*
}

Human Development and Family Studies, College of Home Science, GBPUAT, Pantnagar, India

*Corresponding author

\begin{tabular}{|l|}
\hline Key w o r d s \\
Media, Electronic \\
media, Influence
\end{tabular}

\section{A B S T R A C T}

In present time electronic media have greater influence on youth. Young generation has tendency to imitate and follow anything which appears 'hip' or 'in'. They are quick to relate and to follow what appears fashionable. Fashion is something that teens wish to fit in which makes them struggle in their everyday life. Thus, the investigation was aimed to assess the role of media and peer in fashion adoptions among young adult girls (18-25 Years) residing in premises of GBPUAT, Pantnagar. A total number 60 respondents were purposively selected for the study. A self-constructed questionnaire was prepared and applied in order to achieve objectives of research. Frequency and percentage were calculated to examine the results of the study area. The findings from this research show that the mass media play an important role in influencing fashion adoption of young adults.

\section{Introduction}

Media influence is when you choose to do something giving priority other then yourself because you want to feel accepted and valued by your friend and social circle it isn't just always doing something against your will. Media and peer influence move parallel. Peer influence is a better way to describe instead of peer pressure how teenager's behaviour is shaped by wanting to feel they belong to a group of friends. Now days "media" is a biggest talk. Youth is very much influenced by media due to the reason that all are in very much contact of mobile phones, internet, magazines, newspapers etc. Due to which it becomes very much difficult to restrict or bound them as it is next to impossible. This fact is accelerated by peer.

Media have both positive and negative consequences. Child becomes more assertive, try something new etc provide opportunity to explore. Some teenagers might choose to try things they normally wouldn't be doing like smoking, drinking etc because they consider it as a part of fashion and in today's epoch to be along with fashion is a necessity. They select 
same colour, design clothes want exactly same hair style etc. Youth is very conscious for their figure especially girls who prefer exercise even take (go slim tonics and syrups) if nothing works out, they choose tummy tucks, slim suit etc. Boys are also no far in this race they go running cycling, gymnasium etc. girls are so much conscious that they even take the risk of poor health, weakness and anaemia. On the other hand, their cosmetic list starts from kajal, lip colour and ends nowhere they are also impressed by brand ambassadors no matter product is of no use. Now days fashion by media is so high that people choose their undergarments that too branded (jockey, dreams, Kelvin, twins etc) no matter how much money wasting it is after all it gives a sense of confidence. Thus, a study was undertaken with following objectives, that includes to assess the attitude of adolescents regarding fashion status. And to identify the prevalence of media in adolescence. Also to assess the choice of youth regarding fashion and attitude towards own body image.

\section{Materials and Methods}

To assess the Role of media in promoting fashion 60 young adults girls, between the age range of 18-25 Years, residing in premises hostel of GBPUAT, Pantnagar were purposively selected as sample of the study. A self-constructed questionnaire was utilized in order to achieve objectives of research. Frequency and percentage were fitted to examine the results of the study area. The findings from this research show that the mass media play an important role in influencing fashion adoption of young adults.

\section{Results and Discussion}

The media provide a necessary and valuable community service; however, unrealistic and stereotypical images of the 'perfect' body type are also common across many forms of media and advertising, including social media. Young people are more exposed to such images as a result of greater access to technology. It is important for parents and young people to think critically about the images they see in the media and understand that they may have been manipulated and are not necessarily humanly achievable looks (Mbabazi, 2004 and GDHR, 2016). The fashion statement in glamour world changes with the season. Accordingly, the teenagers also change their wardrobe. Mostly teenagers give priority to the fashion and style of the day. Even if they are unaware of the world affairs, they will remain aware of the latest fashion. Earlier, people of elite class and business tycoons mostly used to follow the recent trends. But despite of the status of the people every one follows and maintains the present fashion (Super User, 2015).

Table 1 depicts that for majority of girls $(53.33 \%)$ fashion was new look and media is newspaper, TV, magazines, followed by girls $(23.33 \%)$. for whom fashion was being different and media is social networking site rest girls $(23.33 \%)$ think fashion is what suits you and media is anything that gives knowledge. Hoffner and Buchanan (2005) also explained in his study that attractiveness of the TV character associated with the rating of female character with their wishful identification.

This could lead to modelling effect in term of the appearance of the women. Therefore, women are more likely to consciously model their own appearance after the model character. This leads to making TV character appealing as role models to young adults, especially women. This in turn gives an emphasis on the unique connection between audience and the media figures. It was seen that most girls (73.33\%) adopt fashion by own choice and not satisfied with figure some girls $(26.33 \%)$ influenced by peer and satisfied with 
their figure. We have seen that only some girls $(16.66 \%)$ do not compare their figure rest $(83.33 \%)$ compares with friends. half of the girls $(50 \%)$ want to be with latest trend half $(50 \%)$ do not. Most of girls $(63.33 \%)$ avoid fast food when considering figure followed by girls $(36.66 \%)$ who do not. It is seen that only $(2 \%)$ girls suffer from bulimia and (2\%) anorexia nervosa.

Media, peer influence and group conformity can be considered as important determinants in food acceptability and selection. Clothing offers teens a means of self-expression or a way of coping with social situations argue that self-expression is especially important to the echo-boomers and found that clothing style, look and fit were the three most important clothing selection criteria used by 13 to 19 year females also found that this age group was preoccupied with social acceptance, social affiliation and "coolness" attached to make the "right" clothing choices.

Teens that interact more with peers about consumer matters exhibit a more brandoriented decision-making style (http://ezinearticles.com/?Fashion-and-

Teenagers\&id=141857). Adolescents frequently communicate with their peers prior to making purchases in order to maintain group identity. Similar results were also found in current study (Table 1) that majority of the girls $(23.33 \%)$ prefer media for solution of health and nutrition followed by girls $(16.66 \%)$ who do not and maximum girls $(60 \%)$ sometimes prefer. so many girls $(70 \%)$ are addict to media to select clothing and accessories and prefer media for dress suggestion and prefer brand popular on TV and some girls (30\%) do not and have no personal dress counsellors, take suggestion for friends and relatives.
Teenage girls are not only pressured by magazines to dress like celebrities, but the magazines and media have a big influence on the ways girls physically look. When a very skinny beautiful girl is on the cover of a teen's favourite magazine, they will do whatever it takes to look just like them. This is causing many eating disorders amongst teenage girls, which is changing their lifestyles.

All the girls in the media and magazines are told or forced to be skinny which has an influence to other girls making them want to be skinny like them as well (http://www.ehow.com/facts_5150416_fashio n-important-teens.html1). Table 1 depicts that few girls $(16.66 \%)$ have diet according to media followed by girls $30 \%$ ) who do not and some girls $(53.33 \%)$ sometimes have diet according to media. it is seen that some girls $(13.33 \%)$ consider home magazine's recipe for diet followed by girls $(23.33 \%)$ who do not and $(63.33 \%)$ who sometimes prefer.

It depicts that few girls (10\%) take medicines or tonics to get slim or healthy but majority of girls $(66.66 \%)$ who do not but still some girls $(23.33 \%)$ have taken in past. Among all factors, media presentation of thin image is a major contributor to current high incidence of body dissatisfaction and eating disorders in women (Cash, 2004).

Results indicated that relative to a control group, the exposure to thin-and-beautiful media images adversely influenced the state body image of participants with high internalization levels Elsevier). It was also observed that majority of girls $(80 \%)$ do not use tummy tucks like clothing followed by girls $(20 \%)$ who sometimes use. 
Table.1 Frequency and percentage distribution of Role of media and peer in promoting fashion in young adults. $\mathrm{N}=60$

\begin{tabular}{|c|c|c|c|c|}
\hline Sl.no & Description & Options & $f$ & $\%$ \\
\hline \multirow[t]{3}{*}{1.} & \multirow[t]{3}{*}{ Meaning of fashion. } & New look & 32 & 53.33 \\
\hline & & Being different & 14 & 23.33 \\
\hline & & What suits you & 14 & 23.33 \\
\hline \multirow[t]{2}{*}{2.} & \multirow[t]{2}{*}{ Selection based on. } & Your choice & 44 & 73.33 \\
\hline & & Peer & 16 & 26.33 \\
\hline \multirow[t]{2}{*}{3.} & \multirow[t]{2}{*}{ Satisfied with your figure and personality. } & Yes & 16 & 26.33 \\
\hline & & No & 44 & 73.33 \\
\hline \multirow[t]{2}{*}{4.} & \multirow[t]{2}{*}{ Compare body figure with others. } & Yes & 50 & 83.33 \\
\hline & & No & 10 & 16.66 \\
\hline \multirow[t]{2}{*}{5.} & \multirow[t]{2}{*}{ Want to be always with latest trend. } & Yes & 30 & 50 \\
\hline & & No & 30 & 50 \\
\hline \multirow[t]{2}{*}{6.} & \multirow[t]{2}{*}{ Avoiding fast food when considering figure. } & Yes & 38 & 63.33 \\
\hline & & No & 22 & 36.66 \\
\hline \multirow[t]{3}{*}{7.} & \multirow[t]{3}{*}{ Suffering from health problem. } & Bulimia & 04 & 6.66 \\
\hline & & Anorexia & 04 & 6.66 \\
\hline & & No & 52 & 86.66 \\
\hline 8. & Addict to media to select clothing and accessories. & $\begin{array}{l}\text { Yes } \\
\text { No }\end{array}$ & $\begin{array}{l}42 \\
18\end{array}$ & $\begin{array}{l}70 \\
30\end{array}$ \\
\hline 9. & Prefer brand which is & On TV & 42 & 70 \\
\hline & & Suggested by friend, relative & 18 & 30 \\
\hline 10. & Prefer media for solution of health and nutrition. & Yes & 14 & 23.33 \\
\hline & & No & 10 & 16.66 \\
\hline & & Sometimes & 36 & 60 \\
\hline 11. & What is media. & Newspaper, TV, magazines. & 32 & 53.33 \\
\hline & & Social networking site & 14 & 23.33 \\
\hline & & Anything, that gives knowledge & 14 & 23.33 \\
\hline 12. & Have diet according to media. & Yes & 10 & 16.66 \\
\hline & & No & 18 & 30 \\
\hline & & Sometimes. & 32 & 53.33 \\
\hline 13. & Consider home magazines recepies for diet plan & Yes & 08 & 13.33 \\
\hline & & No & 14 & 23.33 \\
\hline & & Sometimes & 38 & 63.33 \\
\hline 14. & Take medicines or tonics to get slim or healthy. & Yes & 06 & 10 \\
\hline & & No & 40 & 66.66 \\
\hline & & Ever taken & 14 & 23.33 \\
\hline 15. & Use tummy tucks like clothing. & Yes & 00 & - \\
\hline & & No & 48 & 80 \\
\hline & & Sometimes & 12 & 20 \\
\hline 16. & Prefer in daily routine. & Yoga & 08 & 13.33 \\
\hline & & Exercise & 28 & 46.66 \\
\hline & & Cycling & 14 & 23.33 \\
\hline & & No & 10 & 16.66 \\
\hline 17. & Have diet chart. & Yes & 06 & 10 \\
\hline & & No & 54 & 90 \\
\hline 18. & Liked page in facebook. & Health & 16 & 26.66 \\
\hline & & Accessories & 12 & 20 \\
\hline & & Both & 08 & 13.33 \\
\hline & & No & 24 & $40 \%$ \\
\hline 19. & Prefer femina, women's era etc. & Yes & 08 & 13.33 \\
\hline & & No & 28 & 46.66 \\
\hline & & Sometimes & 24 & 40 \\
\hline 20. & Have personal dress designer counsellor & Yes & 00 & - \\
\hline & & No & 18 & 30 \\
\hline & & Prefer media & 42 & 70 \\
\hline 21. & Use stylish footwear to enhance your personality. & Yes & 34 & 56.66 \\
\hline & & No & 26 & 43.33 \\
\hline 22. & Use belt to & Tighten jeans & 20 & 33.33 \\
\hline & & To look good & 22 & 36.66 \\
\hline & & Put stomach in & 18 & 30 \\
\hline 23. & Carrying purse, clutch, side bags, hand bags & For fashion & 36 & 60 \\
\hline & & For functional use & 24 & 40 \\
\hline 24. & Like to purchase & Online & 38 & 63.33 \\
\hline & & Market & 22 & 36.66 \\
\hline 25. & Suggest you friend to be in touch with flipcart, Amazon, voonik & Yes & 46 & 76.66 \\
\hline & & No & 14 & 23.33 \\
\hline
\end{tabular}


Table 1 depicts that few girls (13.33\%) do yoga on daily routine followed by girls $(46.66 \%)$ do exercise $(23.33 \%)$ do cycling and few girls (16.66\%) do not prefer anything. Majority of the girls (90\%) do not have a diet chart very few girls (10\%) have. Some girls $(13.33 \%)$ liked the facebook page related to health and accessories followed by girls $(26.66 \%)$ liked related to health some girls $(20 \%)$ liked accessories some girls (40\%) do not liked. Table 1 result depicts that girls $(13.33 \%)$ prefer femina, women's era etc majority of girls $(46.66 \%)$ do not prefer and $(40 \%)$ girls sometimes prefer. many girls $(56.66 \%)$ use stylish footwear to enhance their personality some girls $(43.33 \%)$ do not. It is also observed that many girls $(33.33 \%)$ use belts to tighten their jeans followed by girls $(36.66 \%)$ use to look good and some girls $(30 \%)$ (Women's fashion belts are the perfect accessories for the last finishing touch! The belts can instantly transform shapeless dresses and tops into chic and upto-date outfits with gorgeous waist lines. (Mbabazi, 2004) use to put stomach in. Most of girls $(60 \%)$ carry purse, side bags, hand bags for fashion followed by girls $(40 \%)$ have functional use. most girls $(63.33 \%)$ likes to purchase online while some girls $(36.66 \%)$ still prefer market. (According to 2014 market trends, a 2014 survey of social networks and buying behaviour "showed significant proportions of shoppers being influenced by (and participating in) social sites and friends during their upcoming holiday shopping," with the results showing: $30 \%$ of shoppers had made a purchase via social media in the last year (up by 12\% from 2014), 49\% planning to make a purchase because of a social referral, and $44 \%$ intending to discover new products via social networks). Majority of girls (76.66\%) suggest their friends to be in touch with flipcart, amazon, voonik, etc followed by girls $(23.33 \%)$ who do not suggest. (The survey looked at social participation and found that $48 \%$ of those surveyed think it is important to share product recommendations via social media networks. Teenagers seek to define themselves through their clothing, experiences, hairstyles, and, most of all, group associations. In all, this experimentation suggests that the adolescent attempts to discover himself/herself through external-rather than intrinsic-stimuli. Accordingly, images from popular culture often provide the external basis from which teenagers will benchmark their thoughts, opinions and associations. Celebrities have one thing in common, other than their successful careers they all have the ability to influence individuals, especially teenagers, into buying a particular product. These celebrities are a few just who hold the power to structurally impact social groups, which places them among a group of highly influential persons in society. Celebrities are more like salespersons. Though they may not explicitly try to persuade their audiences, they are subconsciously altering the thoughts of the public. This is noticeable through celebrity endorsements, press interviews, apparel worn during public events, items favored by celebrities, celebrity-branded products and celebrities' overall brand image all of which create epidemics of societal acceptance among various social groups (Super User, 2015).

According to the finding, mass media and peer plays an important role on changing the young girls. Mass media change the way teens act, dress, and it changes their personal life as well. Was found in this study that young adult girls are very much influenced by media (magazines, tv, social networking sites, celebrities and peer).girls are using clothing like tummy tucks, to shape their body even using belts to put their stomach in using footwear to enhance their personalities these sample girls even compare their body figure 
with their friends. They go yoga, exercise, gym, cycling to achieve good figure some have their regular diet chart also even they consider home magazines recipe for diet planning and prefer media to set their food. Girls liked facebook pages related to health and accessories even prefer media to select clothing and to solve health related problems. Thus, it can be concluded that young adults are more prone to get affected by the glamour and the lavish lifestyle. They are quick to relate and follow what they think is fashionable.

\section{References}

Baker, C.W., T. D. Little, and K. D. Brownell, "Predicting adolescent eating and activity behaviors: the role of social norms and personal agency," Health Psychology, vol. 22, no. 2, 8. T. F. Cash and T. Pruzinsky, Body Image: A Handbook of Theory, Research and Clinical Practice, The Guildford Press, London, UK, 1st edition, 2004.

Clay, D., V. L. Vignoles, and H. Dittmar, "Body image and self-esteem among adolescent girls: testing the influence of sociocultural factors," Journal of Research on Adolescence, vol. 15, no. 4, pp. 451-477, 2005.

Elsevier Volume 2, Issue 1, March 2005,
Pages 74-80

Haciefendioğlu, Ş. (2011). Reklam Ortamı Olarak Sosyal Paylaşım Sitelerive Bir Araştırma, Bilgi Ekonomisive Yönetimi Dergisi, 11 (1): 107- 115. http://ezinearticles.com/?Fashion-and-

Teenagers\&id $=141857$

https://foreverfamilies.byu.edu/Pages/parentin g/Media-and-Clothing-MarketInfluence-on-Adolescent-GirlsWarnings-for-Parents.aspx

Popkin BM, Nielsen SJ. The sweetening of the world's diet. Obes Res. 2003; 11: 1325-1332.

SMG Knowledge, (2012). Türk Tüketicisinin Satın Alma Sürecindeki Davranışları Nasıl Değişiyor, 2012, Online: http://smgconnected.com/turktuketicisinin-satin-alma-surecindekidavranislari-nasil-değisiyor

Sonia H. (2007). Study Reveals Social Media Use, Strategic Communication Management, 11(3): 9

Super User, December (2015), Teens affected by fashion, http://www.textilevalue chain.com/index.php/article/technical/it emlist/user/538-superuser

Van D.J. (2006). The Network Society: Social Aspects of New Media, Sage Publication, Second Edition, London, UK

\section{How to cite this article:}

Shikha Johari, Ragini Mishra and Alka Pandey. 2019. An Assessment on Role of Media in Fashion Adoptions among Young Adults Girls. Int.J.Curr.Microbiol.App.Sci. 8(08): 236-241. doi: https://doi.org/10.20546/ijcmas.2019.808.028 